Vol. 10, N. 2, Year 2017

ISSN: 2037-0830 - DOI: 10.1515/rem-2017-0009

\title{
Teachers' Professional Development on Digital and Media Literacy. Findings and recommendations from a European project
}

\author{
Maria Ranieri ${ }^{\mathrm{a}}$, Isabella Bruni ${ }^{\mathrm{b}}$, Anne-Claire Orban de Xivry ${ }^{\mathrm{c}}$ \\ ${ }^{a}$ University of Florence, Italy, maria.ranieri@unifi.it, ORCID 0000-0002-8080-5436 \\ ${ }^{b}$ University of Florence, Italy, isabella.bruni@unifi.it \\ ${ }^{c}$ Media Animation sbl,Belgium,ac.orban@media-animation.be
}

\begin{abstract}
Media and digital literacy are being increasingly recognized as a fundamental competence for teachers of 21 st century, but teachers' professional development is still far from coping with this emerging need. This paper aims at providing some recommendations for integrating media literacy into in-service teacher training programs. To this purpose, it will present the results of the experimentation carried out in three European training institutions within the framework of the European project e-MEL (e-Media Education Lab, 2014-17). The overall training process was monitored and evaluated ex-ante, ongoing and ex-post. This paper illustrates and discusses the main findings of the experimentation focusing on strengths and challenges for implementing a teacher training program on digital and media literacy. It concludes with some recommendations and more general reflections on future research directions.
\end{abstract}

Keywords: Digital \& media literacy, media education, teacher training, blended-modality, European programs

\section{Introduction}

In the last ten years, teacher training programs started to integrate digital and media literacy as a fundamental topic; clearly, this introduction is still not accomplished, and great differences can be recorded between different European countries in terms of policies and practices. Nevertheless, the European Union is working to provide a common framework on teachers' literacy skills in the contemporary digital society, releasing the Proposal for a European Framework for the Digital Competence of Educators (Redecker \& Punie, 2017). The document identifies six areas of competences such as the capacities of using digital resources and tools for professional engagement, digital teaching and facilitating students' digital literacy skills. Indeed, research in the field pointed out that teachers need adequate training in order to form the digital and media skills of their students (Fernández-Cruz \& Fernández-Díaz, 2016; Lund, Furberg, Bakken \& Engelien, 2014; Prendes, Castañeda \& Gutiérrez, 2010; Scull \& Kupersmidt, 2011). In synthesis, it seems clear that a hiatus exists between the statement of the importance of digital and media literacy for twenty-first century education, the reality of teachers' level of media and digital competences and the existing training programs in media education (Gudmundsdottir, Loftsgarden \& Ottestad, 2014; Lund, Furberg, Bakken \& Engelien, 2014).

\footnotetext{
${ }^{1}$ The article was conceived by all the authors, who contributed to the text as follows: Maria Ranieri wrote the sections Introduction, Literature review, Discussion and recommendations, Conclusion; Isabella Bruni wrote the sections E-Media Education Lab: a program for in-Service teachers, Research questions, Methods, Results; Anne-Claire Orban de Xivry revised all the text. Data providing the ground for the elaboration presented here are fully documented in the following national reports: Bevort, E., \& Schweitzer, E. (2016a). News media education as a citizenship challenge. Report on the e-Lab experimentation. Paris: Canopé-CLEMI; Bevort, E., \& Schweitzer, E. (2016b). Images of sciences in the media. Report on the eLab experimentation. Paris: Canopé-CLEMI; Culot, M., \& Orban de Xivry, A. (2016). National Report Belgium, Report on the e-Lab experimentation. Brussels: Media Animation; Pereira, S., Pinto, M., Moura, P. (2016a). Understanding the Current World. Report on the e-Lab Experimentation. Minho: University of Minho; Pereira, S., Pinto, M., Moura, P. (2016b). Media uses and audiences in the digital environment. Report on the e-Lab Experimentation. Minho: University of Minho.
} 


\section{Teachers' Professional Development on Digital and Media Literacy. Findings and recommendations from a European project \\ Ranieri, Bruni, Orban de Xivry}

This paper aims at exploring how digital and media literacy education can be integrated into teacher training programs through the presentation and discussion of the results of the project e-Media Education Lab (e-MEL, http://emediaeducationlab.eu, 2014-17), a European initiative funded by the Erasmus Plus program. This program involved six countries (Belgium, Finland, France, England, Italy and Portugal) in the design and testing of educational resources for pre- and in-service teacher training in the area of media literacy education. In this paper, we report and comment on the results of training scenarios for in-service teachers, which were experimented in different types of organizations, from university to private association. In the following, we first introduce the context and the training scenarios, and then we describe the methodology and the results of experimentation. The paper discusses the main findings and provides recommendations on how to implement digital and media literacy activities in teacher professional development programs.

\section{Literature review}

Given the reflection on competences for the twenty-first century education, both international bodies and scholars have proposed frameworks of digital and media literacy for teachers. One of the most relevant is the Media and Information Literacy (MIL) Curriculum and Competency framework developed by UNESCO (2011), which identifies three thematic areas: 1. Knowledge and understanding of media and information for democratic discourses and social participation; 2. Evaluation of media texts and information sources; 3. Production and use of media and information. These areas are interrelated and linked with further teachers' skills and knowledges, including understanding the policies to promote MIL and the strategies to manage projects in the classroom, the capacity to teach MIL to their students and the use of technologies to reach different audiences. The model also focuses on teachers' professional development through media and technology by continuously updating both their subject matter skills and their pedagogical knowledge.

Another important reference is the Digital Competence Framework for Educators (DigCompEdu) proposed by the European Union (Redecker \& Punie, 2017). This framework identifies six different competence areas: Area 1 focuses on the professional engagement, such as digital tools for communication and professional collaboration; Area 2 on sourcing, creating and sharing digital resources; Area 3 on managing the use of digital tools in teaching and learning; Area 4 on digital tools and strategies to enhance assessment; Area 5 on the use of digital tools to empower learners; Area 6 on facilitating learners' digital competence through activities on media and information literacy, digital collaboration and problem solving, content creation and wellbeing.

As for the contribution of scholars on digital literacy for teachers, the Krumsvik's works provide an important perspective on the topic $(2008,2011,2014)$. In his first study, Krumsvik stressed the importance of the pedagogical and ethical aspects in conceptualizing teachers' digital competence: 'the teacher's proficiency in using ICT in a professional context with good pedagogic-didactic judgement and his or her awareness of its implications for learning strategies and the digital Bildung of pupils' (2008, p. 283). According to this definition, Krumsvik's model includes four main components: basic ICT skills, didactic ICT competence particularly referring to the specific subject matter, learning and metacognitive strategies and learners' digital Bildung, which encompasses the ethical aspects of using the media. Another definition of teachers' digital competence was recently elaborated by Johannesen, Øgrim \& Giæver (2014): they distinguished the capacity to train students' digital competence (teaching of ICT) from the capacity to use technology to teach disciplines (teaching with ICT) and the capacity to facilitate students' understanding of the role of technology in contemporary society (teaching about ICT).

Beyond the differences among these diverse conceptual models, they all converge in emphasizing how the concept of teachers' digital and media literacy includes different types of knowledge that can be summarized as below (Ranieri \& Bruni, 2018):

- Digital and media knowledge and competences - being able to use effectively media languages and digital tools with the awareness of socio-ethical implications

- Didactic transposition of digital and media knowledge and competences - the capacity to teach the media, applying pedagogical and didactic knowledge to digital technologies

- Didactic transposition of disciplinary contents through the use of media and digital technologies - the ability to use the media to teach a specific subject matter.

Moving from theory to practice, it generally emerges that teachers are barely prepared for teaching digital and media literacy in school. For example, in their large study on teachers' perceptions of digital literacy in Spain, Fernández-Cruz and Fernández-Díaz (2016) found that most teachers did not even know the meaning of this notion when applied to the educational field and were very far from having an understanding of the pedagogical strategies to promote students' digital literacy in school. This data is consistent with the findings of Avery and colleagues (2011): these authors carried out a qualitative research on the spread of media literacy education in primary school and found that only one fifth of teachers knew what media literacy means, while the others tended to identify this concept with the technical-procedural skills associated with computer and Internet use. According to them, media literacy is nothing more than a way of 


\section{Teachers' Professional Development on Digital and Media Literacy. Findings and recommendations from a European project \\ Ranieri, Bruni, Orban de Xivry}

communicating through the computer and knowing technologies. This strongly instrumental vision of media and digital literacy also prevails in a Norwegian study: Johannesen, Øgrim and Giæver (2014) show how in both school and initial training, the emphasis is more on teaching with ICT than teaching about media languages.

Several studies focused on the measurement of the teachers' level of digital and media literacy (Cortina-Perez et al., 2014; Gonzalez Fernandez et al., 2015; Spires \& Bartlett, 2012; Soldatova \& Shlyapnikov, 2015). This is a very loose area. For example, low levels of digital literacy were found among the teachers who participated in the study of CortinaPerez and colleagues (2014), who speak of 'digital illiteracy' and attribute to this lack of skills the inability to adopt innovative digital pedagogy. In another study, Gonzalez Fernandez and colleagues (2015) reported that teachers had adequate levels, but they still expressed the need to reinforce their training through specific professional development programs. In Italy, massive interventions have been promoted by INDIRE since 2000 onwards. In this respect, Parigi (2016) explains how the failure to meet teachers' expectations of improving their digital literacy in the training courses provided by the national body was the main cause of the abandonment and dissatisfaction for most participants.

There are also interesting studies that investigate the relationship between personal and professional use of ICT. Tour (2015), for example, showed how teachers' views of the affordances of digital media were strictly linked to their personal use, which in turn, influenced their professional practices in a very uncreative way.

This brief literature review indicates that teachers' preparation on media and digital literacy is still at the beginning and that much effort should be made to improve teachers' skill in the digital era.

\section{E-media education lab: a program for in-service teachers}

\subsection{Context and aims}

The main idea underpinning the e-MEL project was bridging the gap between the emerging need for teachers' preparation on digital and media literacy and the messy reality of training in this field by designing, delivering and experimenting training resources for teachers' professional development to be published online as open educational resources (OER). The project relied on the large and relevant experience of the consortium in the field of Media Literacy Education 1.

The project was organized in three main phases, as mentioned below:

First Phase. Elaboration of a theoretical framework to represent media literacy education competences and the development of related evaluation tools (Verniers \& Tilleul, 2014). The framework is based on the distinction between media literacy (i.e., knowledge and skills about the media) and media education (i.e., the process of teaching about the media). As for media literacy, three main categories were identified referring to media analysis or production (Table 1): 1. Informational Axis, which includes critical understanding of contents, analysis of languages and representation; 2. Technical Axis, which entails the understanding of how media works, considering the technical aspects such as techniques and interfaces; 3. Social Axis, which refers to the capacity to understand media production and reception context, the role of media in society. The framework also provided the ground for the development of the evaluation tools, each one adapted to the e-MEL programs tested at national level.

Table 1. Key competences framework of the e-MEL project

\begin{tabular}{|c|c|c|c|}
\hline \multirow{2}{*}{$\begin{array}{l}\text { Media } \\
\text { Education } \\
\text { competences }\end{array}$} & $\begin{array}{l}\text { Analysis } \\
\text { competences }\end{array}$ & Didactic axis & $\begin{array}{l}\text { For example, understand advantages and constraints of } \\
\text { ICT in the educational process and its transformative } \\
\text { potential on how to learn }\end{array}$ \\
\hline & $\begin{array}{l}\text { Production } \\
\text { competences }\end{array}$ & Didactic axis & $\begin{array}{l}\text { For example, conduct media production projects in } \\
\text { classrooms }\end{array}$ \\
\hline \multirow{4}{*}{$\begin{array}{l}\text { Media } \\
\text { Literacy } \\
\text { competences }\end{array}$} & \multirow{3}{*}{$\begin{array}{l}\text { Analysis } \\
\text { competences }\end{array}$} & $\begin{array}{l}\text { Informational } \\
\text { axis }\end{array}$ & $\begin{array}{l}\text { For example, produce critical analysis and interpretation } \\
\text { of the media content }\end{array}$ \\
\hline & & $\begin{array}{l}\text { Technical } \\
\text { axis }\end{array}$ & $\begin{array}{l}\text { For example, choose techniques and materials most } \\
\text { appropriate to a particular objective }\end{array}$ \\
\hline & & Social axis & $\begin{array}{l}\text { For example, understand how important the notion of } \\
\text { audience is and identify the different audiences of a } \\
\text { media and characterize them (social, cultural and } \\
\text { economic issues) }\end{array}$ \\
\hline & $\begin{array}{l}\text { Production } \\
\text { competences }\end{array}$ & $\begin{array}{l}\text { Informational } \\
\text { axis }\end{array}$ & For example, write different genres of media messages \\
\hline
\end{tabular}




\section{Teachers' Professional Development on Digital and Media Literacy. Findings and recommendations from a European project Ranieri, Bruni, Orban de Xivry}

Technical For example, master technical processes (production, axis edition, publishing processes, etc.)

For example, take care of the ethical and legal aspects,

Social axis the rights and the duties of the freedom of expression (image, rights, copyrights, insults, defamation) in one's own media production

Second Phase. Design, implementation and experimentation of training scenarios (TS) addressing pre- or in-service teachers. For the design of training scenarios, guidelines and a common template were elaborated, and peer reviewed by the consortium. A collection of 20 training scenarios was gathered and 10 of them were delivered in a blended modality through an online platform called eLAB and was based on Moodle.

Third Phase. Revision, improvement and dissemination of TS as open educational resources (OER). The online platform was rearranged as a resource centre for teacher trainers, providing them with the opportunity to access the full documentation of the project (key competences framework, training scenario description, evaluation tools) and to reuse, update and adapt all e-MEL activities and resources.

This paper focuses on the analysis of the training activities that involved in-service teachers in order to formulate some recommendations about how to develop sustainable and effective training programs on media and digital literacy for in-service teachers. In the next paragraph, we introduce the training scenarios and describe participants' characteristics.

\subsection{Training scenarios and participants}

Three partners out of seven addressed in-service teachers. All of them had relevant experience in the field of media literacy education and teacher training, although the type of organizations was different ranging from an association (Media Animation, Belgium) to a university (University of Minho, Portugal) to a research centre supported by the Ministry of Education (CLEMI, France). An overall number of five training scenarios were designed and tested, varying in terms of theme, duration, and organizational mode. Three training scenarios (Belgium, TS1; France, TS1; Portugal, TS1) focused on news media, especially on how to access information and deconstruct media news agenda: primary and secondary teachers were involved in media analysis exercises, online activities and project work. Another training scenario aimed at deepening the issue of audience, making teachers capable of identifying different media uses and practices, particularly among younger publics (Portugal, TS 2). The last TS tackled the specific theme of the use of scientific images in the media for secondary school teachers (France, TS 2).

81 teachers attended the five training scenarios, including 7 from Belgium, 12 from France, and 62 from Portugal, and most of them were female $(\mathrm{N}=63)$ (Table 4). As for age, the target population was quite old (only 12 people under 40 years) and the level of education was high with most trainees having a bachelor or master's degree. Concerning the previous online experiences, the answers changed according to the national context: in Portugal, almost all teachers had previous e-learning training, while in the other countries, the teachers were divided between those who had previous online learning experiences and those who did not. As for the perceived level of media literacy, the trainees believed that they already had a good level of competences $(\mathrm{N}=52)$; in Portugal, where the sample was bigger than the others, 19 teachers declared to have a low media literacy level.

Table 2. Number of trainees and their characteristics

\begin{tabular}{|c|c|c|c|c|c|c|}
\hline $\begin{array}{l}\text { Trainees } \\
\text { Groups }\end{array}$ & Number & Age & Gender & Education & $\begin{array}{l}\text { Previous online } \\
\text { learning } \\
\text { experience }\end{array}$ & $\begin{array}{l}\mathrm{ML} \\
\text { competences }\end{array}$ \\
\hline MA & 7 secondary & $\begin{array}{l}1-><30 \\
1->30-35 \\
2->36-39 \\
2->40-49 \\
1->50-59\end{array}$ & $\begin{array}{l}\text { 5-> F } \\
\text { 2-> M }\end{array}$ & $\begin{array}{l}\text { 6-> Master } \\
\text { 1-> High } \\
\text { school }\end{array}$ & $\begin{array}{l}\text { 2-> Yes } \\
\text { 5-> No }\end{array}$ & $\begin{array}{l}\text { 3-> Good } \\
\text { 4-> Very Good }\end{array}$ \\
\hline $\begin{array}{l}\text { CLEMI } \\
\text { TS } 1\end{array}$ & 5 primary & $\begin{array}{l}1->30-35 \\
2->40-49 \\
1->50-59\end{array}$ & $\begin{array}{l}\text { 2-> F } \\
\text { 3-> M }\end{array}$ & $\begin{array}{l}\text { 4-> Master } \\
\text { 1-> High } \\
\text { school }\end{array}$ & $\begin{array}{l}\text { 2-> Yes } \\
\text { 3-> No }\end{array}$ & $\begin{array}{l}\text { 4-> Good } \\
\text { 1-> Very Good }\end{array}$ \\
\hline CLEMI & 7 secondary & $2->30-35$ & $5->F$ & 7-> Master & 4-> Yes & 4-> Good \\
\hline
\end{tabular}




\section{Teachers' Professional Development on Digital and Media Literacy. \\ Findings and recommendations from a European project \\ Ranieri, Bruni, Orban de Xivry}

\begin{tabular}{|c|c|c|c|c|c|c|}
\hline TS 2 & & $\begin{array}{l}1->36-39 \\
2->40-49 \\
2->50-59\end{array}$ & $2->M$ & & $3->\mathrm{No}$ & 3-> Very Good \\
\hline $\begin{array}{l}\text { UMinhoT } \\
\text { S } 1\end{array}$ & $\begin{array}{l}27 \text { mix order } \\
\text { of school }\end{array}$ & $\begin{array}{l}4->36-39 \\
15->40-49 \\
8->50-59\end{array}$ & $\begin{array}{l}22->F \\
5->M\end{array}$ & $\begin{array}{l}12-> \\
\text { Bachelor } \\
15->\text { Master }\end{array}$ & $\begin{array}{l}\text { 26-> Yes } \\
1->\text { No }\end{array}$ & $\begin{array}{l}\text { 13-> Low } \\
\text { 14-> Good }\end{array}$ \\
\hline $\begin{array}{l}\text { UMinhoT } \\
\text { S } 2\end{array}$ & $\begin{array}{l}35 \text { mix order } \\
\text { of school }\end{array}$ & $\begin{array}{l}1->36-39 \\
18->40-49 \\
15->50-59 \\
1->60 \text { or }<\end{array}$ & $\begin{array}{l}29->F \\
6->M\end{array}$ & $\begin{array}{l}9 \text {-> Bachelor } \\
24 \text {-> Master } \\
2 \text {-> Doctoral }\end{array}$ & $\begin{array}{l}\text { 34-> Yes } \\
1->\text { No }\end{array}$ & $\begin{array}{l}6 \text {-> Low } \\
27->\text { Good } \\
2 \text {-> Very } \\
\text { Good }\end{array}$ \\
\hline TOTAL & 81 & $\begin{array}{l}1-><30 \\
4->30-35 \\
8->36-39 \\
39->40-49 \\
27->50-59 \\
1->60 \text { or }<\end{array}$ & $\begin{array}{l}\text { 63-> F } \\
18->M\end{array}$ & $\begin{array}{l}\text { 2-> High } \\
\text { school } \\
21 \text {-> } \\
\text { Bachelor } \\
56 \text {-> Master } \\
2 \text {-> Doctoral }\end{array}$ & $\begin{array}{l}68->\text { Yes } \\
13->\text { No }\end{array}$ & $\begin{array}{l}19 \text {-> Low } \\
52->\text { Good } \\
10->\text { Very } \\
\text { Good }\end{array}$ \\
\hline
\end{tabular}

\section{Research questions}

With the aim of investigating the issue of teacher training on media and digital literacy education, this study addressed the following research questions:

What are the main successful and/or challenging aspects of training in-service teachers about media and digital literacy?

Is a blended modality of delivery of training courses on media and digital literacy education sustainable for inservice teachers training?

\section{Methods}

During the intervention, data were obtained through a pre-survey aimed at gathering information about demographics, previous experiences and expectations. At the end of the experimentation, participants filled in a postsurvey on satisfaction, providing suggestions for future implementations. Information about the process was annotated by trainers in a logbook including observations and reflections on significant learning situations, difficulties and possible improvements. The adoption of these tools led to the collection of multiple data that were analyzed by national partners and triangulated to increase trustworthiness and credibility (Lincoln and Guba 1985). National reports were produced and then analyzed to identify highlights and lowlights according to the main target group (i.e., in-service teachers). Since there were differences among the diverse testing contexts, even in terms of sample size, skype call meetings with trainers from each organization were necessary to reach a better understanding of findings. In addition, although strictly speaking our study cannot be defined as a comparative one, the use of a grid to synthesize the main emerging aspects of each context facilitated some comparisons among the different countries. Finally member checking (Cohen, Manion, \& Morrison, 2011) was carried out during the transnational meeting in Brussels (December 2016) to increase the reliability of data analysis and a final report was developed.

This recursive procedure of analysis, synthesis and reviewing brought to the identification of strengths and weaknesses of the implementation of training scenarios, according to four main dimensions: Didactics, referring to TS effectiveness, quality of methods and activities, transferability of resources; Modality meaning the balance between online and offline activities and sustainability; Technology concerning the usability of the platform; and finally Participation, related to teachers' involvement in activities and satisfaction.

\section{Results}

\subsection{What are the main successful and/or challenging aspects of training teachers on media and digital literacy?}

\section{Successful aspects}




\section{Teachers' Professional Development on Digital and Media Literacy. Findings and recommendations from a European project Ranieri, Bruni, Orban de Xivry}

Looking at the TS summaries, most of them dealt with news media and emphasized critical thinking as a necessary skill for citizenship in the Information Society. Trainers highlighted that media analysis was a fundamental activity for media education, which, in their view, should support students in the development of a critical perspective about the media. Consequently, three training scenarios focused on news making and proposed media analysis exercises. As a trainer from Media Animation observed, 'the training scenario was designed to show teachers a number of case studies and methodologies to support critical media analysis' (Culot \& Orban de Xivry, 2016, p. 5). The trainees confirmed this expectation, as it emerged from the post-survey, in 4 cases out of the 5 teachers attending the programme envisaged developing their media analysis competences more than all other competences (Table 3 ).

Table 3 - What competences do you expect to develop through this activity?

\begin{tabular}{lllll}
\hline & $\begin{array}{c}\text { Technical } \\
\text { skills }\end{array}$ & $\begin{array}{c}\text { Media Analysis } \\
\text { competences }\end{array}$ & $\begin{array}{c}\text { Media production } \\
\text { competences }\end{array}$ & $\begin{array}{c}\text { Pedagogical } \\
\text { competences }\end{array}$ \\
\hline MA & $1 / 7$ & $7 / 7$ & $2 / 7$ & $2 / 7$ \\
UMinho1 & $10 / 25$ & $23 / 25$ & $17 / 25$ & $15 / 25$ \\
UMinho2 & $10 / 35$ & $31 / 35$ & $25 / 35$ & $28 / 35$ \\
CLEMI TS1 & $1 / 5$ & $2 / 5$ & $1 / 5$ & $3 / 5$ \\
CLEMI TS2 & $0 / 7$ & $7 / 7$ & $3 / 7$ & $5 / 7$ \\
\hline
\end{tabular}

At the end of the intervention, teachers expressed high levels of satisfaction and interest for the analytical exercises, especially in the Belgian and French contexts where media analysis was a core activity of the training scenario.

Another common aspect across the different countries was the emphasis on transferability. Trainers underlined that the transferability was particularly relevant for in-service teachers' training, since teachers 'are looking for contents and concepts that could feed their courses and reflections' (Culot \& Orban de Xivry, 2016, p. 5). For this reason, activities and resources were selected or designed to facilitate teachers re-using them in their professional life. And teachers reused e-MEL contents and tools even during the experimentation or immediately at the end of it (Culot \& Orban de Xivry, 2016, p. 8; Bevort \& Schweitzer, 2016b, p. 12). The attention put by the partnership on transferability positively influenced the teachers' perceptions related to this aspect; as shown in Table 4, most teachers found that the competences developed during the programme as well as the teaching materials provided by e-MEL were likely to be transferred to their professional contexts.

Table 4 - Trainees' level of agreement on transferability of competences and resources

The competences developed in the course will be useful for my professional life

I expect to use this training scenario or parts of it in my professional context

\begin{tabular}{lllllllllll}
\hline & $\mathrm{U} 1$ & $\mathrm{U} 2$ & $\mathrm{MA}$ & $\mathrm{CL} 1$ & $\mathrm{CL} 2$ & $\mathrm{U} 1$ & $\mathrm{U} 2$ & $\mathrm{MA}$ & $\mathrm{CL} 1$ & $\mathrm{CL2}$ \\
Strongly Disagree & 0 & 0 & - & - & - & 0 & 0 & - & - & - \\
Disagree & 0 & 1 & - & - & - & 0 & 1 & - & - & - \\
Uncertain & 0 & 1 & - & - & - & 1 & 3 & 1 & - & - \\
Agree & 5 & 6 & 2 & 4 & 1 & 4 & 7 & 1 & 4 & 1 \\
Strongly Agree & 19 & 20 & 3 & 1 & 1 & 19 & 17 & 3 & 1 & 1 \\
TOT & 24 & 28 & 5 & 5 & 2 & 24 & 28 & 5 & 5 & 2
\end{tabular}

Issues and challenges

The analysis of national reports revealed that a recurrent challenge for trainers was the management of the online training process, especially for feedback delivery; teachers expected a continuous presence of trainers in the platform. 


\section{Teachers' Professional Development on Digital and Media Literacy. Findings and recommendations from a European project \\ Ranieri, Bruni, Orban de Xivry}

For some trainers, 'the experimentation was another task to add to an already busy agenda as professors and researchers' (Pereira et al., 2016a, p. 8), and then the workload of giving constant guidance and feedback on teachers' activities was not affordable. More generally, during the member check session, the trainers commented that the teachers' expectations were higher than the trainers' possibilities to support them. Trainees, indeed, were looking for an 'always-on trainer', even at night.

The discussion around this issue was prolific and two complementary strategies were drawn for the in-service teacher settings. According to some trainers, a suitable solution could be to figure out the trainer as a community manager who fosters teachers' active participation and cooperation. Other trainers believed that the challenge of providing trainees with continuous and prompt feedback could be coped through a professional community of practice, where one can rely on peer support. Following the first strategy, the trainer keeps a central role in terms of time and energy spent in community management, while the adoption of the second strategy entails a low involvement of the trainer and could be particularly effective with small groups.

The workload was a challenge not only for trainers but also for trainees. As an example, a teacher from Belgium stated that he needed up to 3 times the number of hours indicated for the completion of the TS, particularly referring to media analysis and production (Culot \& Orban de Xivry, 2016). During the discussion, the trainers tried to explain this mismatch between the teachers' needs and course delivery; according to them, the teachers were not used to engaging with media production and analysis, and this had an impact on their feeling of not being able to achieve the tasks.

As far as trainees' participation is concerned, from the national reports, another relevant issue emerges: the lack of institutional support did not allow the in-service teachers to dedicate enough time and energy to the training. Even when the training was institutionally recognized as an activity of professional development and formative credits were attributed to the teachers, like in Portugal and Belgium, the lack of support was still a problem: as a trainer observed, 'the organisation of in-service teachers training requires a real commitment of all the stakeholders (institution, participants...) while taking account of the constraints (workload, time). These training activities cannot remain a matter for the «most engaged» ones.' (Bevort \& Schweitzer, 2016b, p. 14). One consequence was that the training was usually accomplished after work, sometimes very late in the night. Obviously, this affected the teachers' involvement negatively, as the available time was too short, and the time dedicated to training was not the best to achieve better performance.

\subsection{Is a blended modality of delivery of training courses on media and digital literacy education sustainable for in- service teachers training?}

Coming to the course delivery, all TS were based on a mix of face-to-face and online activities, which aroused different reactions and reflections relating to their weaknesses and strengths. On one hand, trainers from Portugal or France observed that the blended-modality was a good strategy for teachers' involvement as it supported 'the inclusion of teachers from a vast geographical range' (Pereira et al., 2016a, p. 11). Moreover, this modality provided teachers with 'the advantage of working at their own pace' (Culot \& Orban de Xivry, 2016, p. 6). On the other hand, face-to-face sessions were reported to be essential for interaction and social grounding, deeply contributing to the success of the learning process. This aspect was analyzed and discussed during the consortium meeting, and trainers agreed on the opportunity to plan at least two face-to-face meetings, at the beginning and the end. Indeed, they are important 'to present more easily the module and to solve immediately some problems' as well as to provide 'a precise and qualitative feedback' (Bevort \& Schweitzer, 2016a, p. 12).

As for the use of online platform, most trainees agreed that Moodle ergonomics was not encouraging; the navigation patterns was found uneasy since linearity makes it 'difficult to go back to previous activities and to move through menus' (Bevort \& Schweitzer, 2016a, post 22). Even the trainers manifested a similar feeling stating that the platform was 'barely flexible, restricting the way contents could be presented' (Pereira et al., 2016a, p. 11). According to them, the cognitive effort of using an online environment could partially explain the teachers' drop-out during the course. The French experimentation is very telling from this point of view; during the presentation of the training scenario, teachers thought that all activities were very easy for them, but the course proved to be challenging and the trainer reported about the conceptual and technical difficulties connected to the online work since the very beginning. Only two teachers out of seven finalized the course, and they agreed on the lack of confidence in attending an online programme: 'most trainees were not digitally able and maybe they were afraid to use the platform, to upload their documents and even to do the group work' (Bevort \& Schweitzer, 2016b, post 12). These considerations about the lack of familiarity with the online environment were also confirmed by the tendency of several teachers to use more common tools and platforms to communicate and collaborate; when possible, many of them preferred using services that they were already familiar with instead of wasting time to familiarize with the platform.

\section{Discussion and recommendations}

Starting from the evidence gathered through the analysis of national reports, in this section, we draw some recommendations for future implementation of blended training on digital and media literacy for in-service teachers. 


\section{Teachers' Professional Development on Digital and Media Literacy. Findings and recommendations from a European project Ranieri, Bruni, Orban de Xivry}

The recommendations have been organized into four categories, including didactic aspects, blended modality, technology and participation. Since they are based on a small sample, they should be intended as a first step towards the systematization of suitable conditions for implementing in-service teacher training in the media literacy field.

\subsection{Didactics}

\section{Emphasis on media analysis activities}

When comparing the different experiences, all media analysis activities proved to be effective and enjoyable for the participants who found them relevant and appropriate. Although we are living in the era of 'spreadable media' (Jenkins, Green, \& Sam Ford, 2013) where the emphasis is on content production and sharing, the attention to media analysis and critical thinking seems to be still relevant. Consistent with the international frameworks on media and digital competence for teachers (Unesco, 2011; Redecker \& Punie, 2017), which highlight the importance of information literacy and media languages, we recommend to always include analytical exercises of critical understanding of media and information in teachers' training, leveraging on usable resources fitting with current professional practices.

Transferability of activities and resources

As underlined by several scholars (Johannesen et al., 2014; Krumsvik, 2014; Ranieri \& Bruni, 2018), when thinking about teachers' digital competence, it is essential to consider the teaching transposition of digital and media knowledge and competences: in-service teachers attending a course expect to transfer what they have learnt to their professional contexts and this was corroborated by e-MEL experimentation. We recommend keeping this in mind when designing the training activities for teachers; these should facilitate the teachers to adopt the teaching materials delivered in the course and their adaptation to the school context.

\subsection{Modality}

Need of a minimum number of face-to-face meetings

When coming to the modality of delivery, it emerged that some teachers are still not confident with online platforms, even for the intrinsic workload linked to the use of a new environment. Moreover, some teachers consider face-to-face lessons more significant in terms of learning, especially for deepening the topics and giving/receiving an effective and timely feedback. At the same time, the trainers reported face-to-face sessions as essential moments for interaction. However, they also stated that the blended modality was fundamental to allow in-service teachers to be involved. Therefore, we suggest planning at least two face-to-face meetings, one at the beginning and the other at the end of the course to introduce the training scenarios and the learning environment (see below: Technology) and provide the final feedback.

\section{Balanced workload of analysis and production activities}

As emerged from the national reports, many teachers perceived the workload to be too heavy as if the real effort needed to carry out the media analysis and production activities on the platform was underestimated. We recommend planning more time for online work and giving a slower pace for it.

\subsection{Technology}

\section{Technological familiarization phase}

The experimentation showed the importance of guiding participants in the exploration of platform features in order to verify their level of digital competence and ensure continuous attendance of the course. A good strategy could be to propose a specific module as a first step in order to familiarize with the platform and the tools involved in the online work. As showed by some national research (Cortina-Perez et al., 2014; Gonzalez Fernandez et al., 2015; Spires \& Bartlett, 2012; Soldatova \& Shlyapnikov, 2015), the level of digital competence of teachers could not be taken for granted, that is why it becomes essential to familiarize them with e-learning services before delivering an online course.

\section{e-Lab platform as a hub of online resources}

During the experimentation, it emerged that some teachers were somehow resistant towards the online platform, preferring other tools, like common online services that they were already using in everyday life. We can say that some teachers showed a sort of ecological approach towards technology, which led them to accept working online only once the added value of the platform was clear. From this point of view, rather than frustrating users to frame all activities within the e-learning management system, it could be better using the platform as a HUB of other specific online services. We suggest future trainers to integrate other tools in the platform; this could also be a useful strategy to overcome the narrow boundaries of traditional platforms such as Moodle. 


\section{Teachers' Professional Development on Digital and Media Literacy. Findings and recommendations from a European project Ranieri, Bruni, Orban de Xivry}

\subsection{Participation}

\section{Build institutional support}

As stressed by almost all the participants, the main obstacle for active participation in the professional development programme was the lack of institutional support, which had negative consequences in terms of time to dedicate to the training. Although in some contexts, the training was formally recognized as a professional activity, this was not enough. What the teachers really needed was the commitment of their local and national institutions (from the school to the National Ministry of Education) to support concretely their training activities, such as giving free time to be dedicated to professional learning.

\section{Limitations}

Although this study led us to a better understanding of how to approach in-service teachers' training on media and digital literacy, it has some limitations that impact on the generalization of its results. In fact, the general sample was small and there were several differences between the different national contexts. As a strategy to control these limitations, we run repeated sessions of member checking. In addition, it must be observed that the trainers participating in the experimentation were very experienced teachers and/or educators active in media literacy education. Their expertise and involvement in the member check process should have increased the reliability of the analysis and its conclusions.

\section{Conclusions}

While media and digital literacy are defined as key competences for teachers today, research on the topic has shown that, generally, teachers have low levels of digital skills and their training on digital education fails to meet the needs. Through the e-MEL project, the partners developed a series of open training scenarios, and analyzed enablers and barriers of teachers' professional development in the digital field. Among the enablers, the availability of transferable training resources proved to be a relevant factor; access to good practices provided teachers with concrete examples of how teaching about the media may work. In parallel, the emphasis on media analysis and critical thinking revealed to be motivating for teachers who decided to dedicate their time to take part to the training process. However, there were several obstacles to the teachers' participation including the workload, time pressure, low level of technical skills and the lack of institutional support. This latter seems to be particularly relevant. If training is not framed within an institutional context, which recognises their value by giving time and incentives, hardly teachers' professional development may become a systematic approach to innovate education systems today.

\section{Acknowledgement}

This study was carried out within the framework of the European funded project e-MEL (e-Media Education Lab) (Erasmus Plus Programme, KA2, 2014-17, EC Project Number: 2014-1-BE01-KA200-000900). All contents of this paper are the sole responsibility of the University of Florence (IT) and can in no way be taken to reflect the views of the European Commission.

\section{References}

Avery, A., McDougall, J., \& Pritchard, A. (2011). Every Child Matters and Media Literacy: Perceptions and Connections. Critical Commentary, 4(1), 35-48.

Bevort, E., \& Schweitzer, E. (2016a). News media education as a citizenship challenge. Report on the e-Lab experimentation. Paris: Canopé-CLEMI.

Bevort, E., \& Schweitzer, E. (2016b). Images of sciences in the media. Report on the e-Lab experimentation. Paris: Canopé-CLEMI.

Cohen, L., Manion, L., \& Morrison, K. (2011). Research Methods in Education (7th ed.). London and New York: Routledge.

Cortina-Perez, B., Gallardo-Vigil, M. A., Angeles Jimenez-Jimenez, M. et al. (2014). Digital illiteracy: a challenge for 21 st century teachers. Cultura y educacion/Culture and Education, 26(2), 231-264.

Culot, M., \& Orban de Xivry, A. (2016). Report on the e-Lab experimentation. Brussels: Media Animation.

Fernández-Cruz, F. J., \& Fernández-Díaz, M. J. (2016). Generation Z's Teachers and their Digital Skills. Comunicar, 46, 97-105.

Gonzalez Fernandez N., Gozalvez Perez V., Ramirez Garcia A. (2015). The media competence in the non-university teachers. Diagnostic and training proposals. Revista de Educacion, 367, pp. 117-146. 


\section{Teachers' Professional Development on Digital and Media Literacy. Findings and recommendations from a European project Ranieri, Bruni, Orban de Xivry}

Gudmundsdottir, G.B., Loftsgarden, M., \& Ottestad, G. (2014). Nyutdannede laerere: Profesjonsfaglig digital kompetanse og erfaringer med IKT i laererutdanningen. Senter for IKT i utdanningen

Krumsvik, R. J. (2008). Situated learning and teachers' digital competence. Educ Inf Technol, 13, 279-290.

Krumsvik, R. J. (2011). Digital competence in Norwegian teacher education and schools. Högre utbildning, 1(1), 39-51.

Krumsvik, R. J. (2014). Teacher educators' digital competence. Scandinavian Journal of Educational Research, 58(3), 269-280.

Johannesen, M., Øgrim, L., \& Giæver, T. H. (2014). Notion in motion: Teachers' digital competence. Nordic Journal of Digital Literacy, 4, 300-312.

Jenkins, H., Ford, S., \& Green, J. (2013). Spreadable media: Creating value and meaning in a

networked culture. New York: New York University Press.

Lincoln, Y.S., \& Guba, E.G. (1985). Naturalistic inquiry. Beverly Hills, CA: Sage.

Lund, A., Furberg, A., Bakken, J., \& Engelien, K. L. (2014). What Does Professional Digital Competence Mean in Teacher Education? Nordic Journal of Digital Literacy, 9(4), 281-299.

Parigi, L. (2016). Balancing between ICT training and reflective practice in teachers' professional development. $T D-$ Tecnologie didattiche, 24(2), 11-121.

Pereira, S., Pinto, M., Moura, P. (2016a). Understanding the Current World. Report on the e-Lab Experimentation. Minho: University of Minho.

Pereira, S., Pinto, M., Moura, P. (2016b). Media uses and audiences in the digital environment. Report on the e-Lab Experimentation. Minho: University of Minho.

Prendes, M.P., Castañeda, L., \& Gutiérrez, I. (2010). Competencias para el uso de TIC de los futuros maestros. Comunicar, 35, 175-182.

Ranieri, M., \& Bruni, I. (2018). Digital and Media Literacy in Teacher Education: Preparing Undergraduate Teachers Through an Academic Program on Digital Storytelling. In Cubbage, J. (Ed), Handbook of Research on Media Literacy in Higher Education Environments. Hershey, PA: IGI Global.

Redecker, C., \& Punie, Y. (2017). Digital Competence Framework for Educators (DigCompEdu). Brussels: European Union.

Scull, T. M., \& Kupersmidt, J. B. (2010). An Evaluation of a Media Literacy Program Training Workshop for Late Elementary School Teachers. Journal of Media Literacy Education, 2(3), 199-208.

Spires, A. A., \& Bartlett, M. E. (2012). Digital Literacies and Learning: Designing a Path Forward. Friday Institute White Paper Series Number Five. Retrieved from: https:/www.fi.ncsu.edu/wp-content/uploads/2013/05/digitalliteracies-and-learning.pdf

www.fi.ncsu.edu/whitepapers

Soldatova, G. U., \& Shlyapnikov, V. N. (2015). Digital Competence of Russian School Teachers. Psikhologicheskaya Nauka I Obrazovanie, 20(4), 5-18.

Tour E. (2015). Digital mindsets: Teachers" technology use in personal life and teaching. Language Learning \& Technology, 19(3), 124-139

UNESCO (2011). Media and Information Literacy (MIL) Curriculum and Competency framework. Paris: UNESCO.

Verniers, P. \& Tilleul, C, (2014). Media Literacy Key Competences frame for teachers training. Retrieved May 25, 2017 from http://e-mediaeducationlab.eu/wp-content/uploads/2017/05/Output-1-Media-Literacy-Key-Competencesframe-for-teachers-training.pdf 